Construction of academic integrity scale

Ramdani, Zulmi $\$

Universitas Gadjah Mada, Yogyakarta, Indonesia (zulmiramdani94@gmail.com)

\title{
Abstract
}

This study aims to create a measure of academic integrity as an effort in anticipating the problems of plagiarism and other academic violations. The concept of academic integrity comes from Keohane (1999) which is defined as an individual's commitment to positive values so as to be able to act and behave accordingly in creating a good academic situation. This research uses semi-construction approach which is divided into several stages. (1) Open ended-questionnaire; (2) Content Validity Aiken's; (3) Testing of discriminating power; (4) Confirmatory Factor Analysis (CFA) \& (5) Validity of Concurrent. There were 7 items dropped during content validation stage ( $\mathrm{rater}=25, \mathrm{v}=0.63 \& p>0.05$ ). After that, testing of discrimination power with the number of subjects 60 people was administered and it resulted 11 items dropped $(r=0.3)$. A total of 32 items were analyzed CFA $(n=254)$ with KMO-Bartlett's Test result of (0.921) and significance (0.001), and it resulted 17 items corresponding to each construct. The score of reliability scale $(r=0.866)$. While for external validity test of academic integrity correlated with optimism $(n=194, r=0.694)$.

Keywords: academic integrity; psychometric properties; semi-construction approach 


\section{Construction of academic integrity scale}

\section{Introduction}

One form of the gap in education is the existence of plagiarism activities (Park, Park, \& Jang, 2013). This phenomenon refers to a behavior whereby an individual acknowledges and produces a work of another person as a result of the individual itself, without specifying the source of their work (Lim \& Nather, 2015). Such actions not only damage the educational system that essentially aims to get a virtuous person but a separate criticism for the government as an institution that ensures the continuity of education in Indonesia (Kemendikbud, 2003).

In 2013, the academic staff of the Faculty of Medicine of the University of Indonesia found nearly 40 very similar student writings on one of their learning modules (Herqunanto, 2013). The same case also occurred in Yogyakarta by a doctor who had to be abandoned his title because his work is considered a result of plagiarism and, more crucially concerned are not allowed to appear at various scientific and research events (Mulyana, 2010). In addition, the action is also almost happening in various universities in the world, such as about 50 $78 \%$ of students in South Korea do a good cheating action when they are in exams or when doing homework (Park et al., 2013).

The behaviors that lead to plagiarism above are caused by internal and external factors (Francis, Clark, \& Erskine, 2015). External factors include policies and systems that have not yet fully established strict rules of plagiarism (Azulay, Barnes, \& Gilleland, 2013). In contrast to existing systems in advanced countries like the United State of America that have established a comprehensive set of rules regarding non-ethical behavior in the academic environment. One of them is the enforcement of guidelines at several universities there, such as "the Books of Academic Integrity at Curtin for Student Guidelines for Avoiding Plagiarism” (Curtin University, 2015). Apart from that, internal factors play a very dominant role in creating this plagiarism behavior (Kisamore \& Jawahar, 2007). Strong characters that have not been awakened in the individual making the opportunity to behave immorally is getting bigger (Comas-forgas \& Sureda-negre, 2010). One of them is the integrity problem (Comas-forgas \& Sureda-negre, 2010).

Integrity in the Oxford Dictionary defined as "quality of being honest and having strong morality" (Jahja, 2007, p. 47). This concept refers to the extent to which individuals think and act honestly and have strong morality. This concept was first developed by Rogers in (Peterson \& Seligman, 2004), as feelings experienced, recognized, and acknowledged by the individual and able to communicate them when necessary. Rogers's understanding of integrity arose in response to dissatisfaction with Kohlberg's theory of moral development in accepting the roles of self (Peterson \& Seligman, 2004). Kohlberg's 1976 study (as cite in Peterson \& Seligman, 2004) reveals that his theory which explains that moral understanding is guided by the development of logic, is unable to answer why moral understanding does not guarantee individuals perform moral acts. So in this case the self is able to explain the problem, which then brings the concept of integrity is growing in various aspects of individual life (Peterson \& Seligman, 2004).

For about 50 years, many studies have tried to construct this character. There are some conceptual definitions given by Peterson and Seligman (2004) who assume integrity as a behavior consistent with shared values, different from morals, and can also be an alternative in determining the quality of individuals in interaction with society. The history of the emergence of this concept of integrity was adopted from the various definition derived as the result of critical thinking on psychological theories that focused only on the unconsciousness, mentality, and environmental dominance (Darwinism), which then created a new, more humane movement and one of them produced a construct this integrity (Peterson \& Seligman, 2004).

Miller and Schlenker's 2007 study found several inventions related to integrity issues (Mauler, 2006); (1) Integrity is related to important principles in individual self-concept; (2) elicits behaviors consistent with their 
principles, and (3) stronger as a unity of character. The explanation of these dimensions leads to progress in the development of a measure of integrity. Many other studies have revealed how this integrity becomes an individual support force in maximizing the choices it takes and making it an authentic form of behavior (Peterson \& Seligman, 2004). This is what brings the personality style to be more responsible and more selective in choosing the behaviors that suit their compatibility. In addition, this integrity can bring the individual to know its advantages and disadvantages, which will directly affect the mindset of the future. Where this will increase the confidence that may be a force in determining the right decision (Peterson \& Seligman, 2004).

The above explanation gives an idea of the importance of integrity in the development of individual self. So in the end this character will lead to ethical behavior. Although there have been many measurements made to measure individual integrity such as Leader Integrity Scale (Craig \& Custafson, 1998), Perceived Leadership Integrity Scale (Mccann \& Holt, 2009), \& Cross-Cultural Adaptation of Integrity Scale in American Latin (Fortmann, Leslie, \& Cunningham, 2002), yet no one has comprehensively developed a measuring instrument suitable with academic culture in Indonesia, especially in college environment.

The integrity, character that can be built within the academic context will create a good system of higher education (Keohane, 1999), because it has a sound academic standard, is able to develop scientific progress and can prepare the responsible young generation as part of a civilized society (Jimenez \& Garza, 2017). More details Keohane set five values that must exist in building academic integrity, namely honesty, trust, fairness, respect, and responsibility (Keohane, 1999). This behavior will also result in a balance between aspects that will ultimately collaborate to create an atmosphere of character education (Devine \& Chin, 2018). Integrity brings the individual to know its advantages and disadvantages, which will directly affect the mindset of the future (Bultas, Schmuke, Davis, \& Janice, 2017). Where this will increase the confidence that may be a force in determining the right decision (Peterson \& Seligman, 2004). This concept is related to the optimism constructs that leads the individual to positive self-control (Bultas et al., 2017).

This optimism has equality with other constructs in terms of future orientations such as hope and future-open minded, as a result of the quality of individual integrity (Scheler \& Carver, 1987). People with integrity will tend to virtually have activities that lead to their long-term goals and all of those behaviors focus on their future goals (Peterson \& Seligman, 2004). Individuals who have optimism will have a strong expectation of their future, while pessimistic individuals are unsure of their future and such behavior depends on the integrity of each individual (Boyle, Saklofske, \& Matthewes, 2015).

Previous studies conducted in formulating the concept of academic integrity have been widely practiced, but no one has been a semi-construction approach (Hinkin, Tracey, Enz, \& Tracey, 1997). The advantage to being gained from using this method is in getting a comprehensive information from collaborations between theoretical concepts that have been validated and the reality in the field (Hinkin et al., 1997). In Indonesia, it having finished a modification of the scale of academic integrity but has not used a test of construct validity (Firmantyo \& Alsa, 2016). Similarly, existing integrity tests are only popular in the industry and organizational contexts (Bazzy \& Woehr, 2017). So the purpose of this research is to conduct semi construction of academic integrity measure in the Indonesian context.

\section{Method}

\subsection{Research Subject}

The subject is a student at the University of Gadjah Mada, which is randomly selected based on the population of the students in more than 17 faculties in the campus environment with a total sample of about 533 subjects. Subjects divided to 60 respondents for open-questionnaire, 25 raters, 254 respondents on factor analysis, and 194 subject for concurrent validity). 


\subsection{Design}

The design in this study is a semi-construction approach, which will be done scale design using a collaboration of theoretical studies with information directly obtained from field data (Hinkin et al., 1997). The advantage of using this semi-construction design is to reinforce existing theories and to multiply the behavioral indicators as much as possible (Hinkin et al., 1997). Then the psychometric property tests, including content validity, discriminating power, confirmatory factor analysis, and external validity concurrent are examined.

\subsection{Research Instruments}

This study uses the concept of integrity conveyed by Keohane, where integrity is a commitment possessed by individuals about the positive values that are owned so as to act and behave accordingly in creating a good academic situation (Keohane, 1999). There are 5 aspects that exist in this integrity constructs that is honesty, trust, fairness, respect, and responsibility. The measuring instrument is based on the conformity between the concepts conveyed by (Keohane, 1999), with the discovery in the field of study results in a closed questionnaire. The total item made amounted to 50 items, with the spread evenly on its aspects. To find out the external validity of this scale, concurrent validity tests with other constructs are considered to have theoretical relevance. The scale of optimism is used to know the correlation and independence of this academic integrity scale. The optimism scale used is the result of adaptation by (Wahyono, 2004), with reliability about 0.930 , and has good test-retest.

\subsection{Manual and Scoring}

The scale of academic integrity created amounted to 50 items with all of them being favorable dimensions. This is based on the concept that is made is a positive character, so that the item made in any positive character all (Peterson \& Seligman, 2004). The goal is to find the strength of the individual rather than see his weakness. The scale is based on using Likert guidance continuum from 1-5 from Start response Very Appropriate (5), Appropriate (4), Neutral (3), Inappropriate (2), and Very Inappropriate (1).

\section{Results}

\subsection{Content Validity}

Aiken has formulated the Aiken's V formula for calculating the content validity coefficient based on the results of an expert panel of $\mathrm{n}$ items on an item in terms of the extent to which the item represents the measured constants (Azwar, 2016). Rater numbered 25 people with a background of psychological master student education is considered to have a holistic understanding of the suitability of the measuring tools with the concept given (Aiken, 1985). See table 1 for the validity scores each item.

\section{Table 1}

Aiken Validation Results (Aiken's V)

\begin{tabular}{clclclclcc}
\hline Item & V & Item & V & Item & V & Item & V & Item & V \\
\hline 1 & 0.69 & 11 & 0.85 & 21 & 0.71 & 31 & 0.69 & 41 & 0.67 \\
2 & 0.52 & 12 & 0.88 & 22 & 0.82 & 32 & 0.83 & 42 & 0.69 \\
3 & 0.82 & 13 & 0.69 & 23 & 0.75 & 33 & 0.74 & 43 & 0.78 \\
4 & 0.86 & 14 & 0.63 & 24 & 0.89 & 34 & 0.55 & 44 & 0.84 \\
5 & 0.79 & 15 & 0.64 & 25 & 0.62 & 35 & 0.76 & 45 & 0.84 \\
6 & 0.8 & 16 & 0.59 & 26 & 0.88 & 36 & 0.7 & 46 & 0.68 \\
7 & 0.7 & 17 & 0.78 & 27 & 0.72 & 37 & 0.82 & 47 & 0.65 \\
8 & 0.8 & 18 & 0.75 & 28 & 0.82 & 38 & 0.7 & 48 & 0.83 \\
9 & 0.92 & 19 & 0.83 & 29 & 0.64 & 39 & 0.68 & 49 & 0.8 \\
10 & 0.59 & 20 & 0.72 & 30 & 0.49 & 40 & 0.55 & 50 & 0.76 \\
\hline
\end{tabular}

Note. V showed the coefficient score from the testing content validity. The criteria V is about 0.63 (Sig. 0.38 with rater 25 ). The coefficient under the V criteria shows the item is bad and not followed again in the next testing. See more on the table "Aiken's V” (Aiken, 1985). 
Using the calculation of Aiken's formula $(\mathrm{V}=\Sigma \mathrm{S} /(\mathrm{n}(\mathrm{c}-1))$, the validity coefficient with p-value $(0.038)$ and rater 25 , the validation value is 0.63 . So based on the calculation result in the above table , there are about seven elements that fall on the content validity stages, namely item number 2, 10, 16, 25, 30, 34, and 40. The rest of the item that can still be used is as many as 43 items (Aiken, 1985).

\subsection{Discrimination Power}

Item discriminating power (see table 2) is the extent to which item is able to distinguish between individuals or groups of individuals who own and who do not have attributes measured (Azwar, 2016). Item remaining amounted to 43 fruit discriminant test using SPSS to 60 respondent research, yielding data as follows:

\section{Table 2}

Results of discriminating power

\begin{tabular}{llllllllllll}
\hline Item & rix & Item & rix & Item & rix & Item & rix & Item & rix & Item & rix \\
\hline 1 & 0.297 & 8 & 0.207 & 15 & 0.608 & 22 & 0.596 & 29 & 0.605 & 36 & 0.632 \\
2 & 0.279 & 9 & 0.486 & 16 & 0.487 & 23 & 0.409 & 30 & 0.416 & 37 & 0.643 \\
3 & 0.255 & 10 & 0.363 & 17 & 0.356 & 24 & 0.485 & 31 & 0.348 & 38 & 0.307 \\
4 & 0.463 & 11 & 0.504 & 18 & 0.250 & 25 & 0.423 & 32 & 0.383 & 39 & 0.311 \\
5 & 0.258 & 12 & 0.272 & 19 & 0.641 & 26 & 0.472 & 33 & 0.560 & 40 & 0.580 \\
6 & 0.432 & 13 & 0.327 & 20 & 0.562 & 27 & 0.648 & 34 & 0.608 & 41 & 0.565 \\
7 & -0.54 & 14 & 0.257 & 21 & 0.363 & 28 & 0.238 & 35 & 0.562 & 42 & 0.683 \\
Total & & & & & & & & & & 43 & 0.262 \\
\hline
\end{tabular}

Note. Rix shows the scores from the SPSS that means the item can discriminate each other. Score has gotten from the bivariate measurement on SPSS.

Based on the criteria submitted by (Azwar, 2016), has the discrimination power index ranges from a minimum (>0.3). From the calculation of SPSS, it is found that there are some items that have discrimination score less than 0.3 . The items are number $1,2,3,5,7,8,12,14,18,28$, and 43 . There are about 11 items that do not meet the criteria of a good discrimination index, even in item 7, is minus, which means the item number 7 is a misleading respondent or unable to distinguish between individual score with the total score. From the results of the discrimination power, obtained item remaining as much as 32 items. This amount is fairly safe to do factor analysis, because given the spread item per-aspect is still very uniform, although there are some aspects that live some items only.

\subsection{Confirmatory Factor Analysis}

One of the objectives of factor analysis is to find out whether the constructs created have a good correlation between them and also to test the construct validity of a variable. Adequacy of samples is the first thing to be considered in doing factor analysis. The minimum number of samples that must be present for factor analysis is 100-150 respondents. In this study, the respondents involved were as many as 254 respondents.

Choosing Variable - This stage is the prefix stage before factor analysis can be performed. In this stage, there are two things that need to be done so that factor analysis can be carried out, the first is to determine the value of Bartlett's Test of Sphericity, which is used to determine whether there is a significant correlation between variables, and the second is Kaiser-Meyer-Olkin (KMO) Measure of Sampling Adequacy, which is used to measure sample adequacy by comparing the observed correlation with the partial correlation coefficient (Chizanah \& Hadjam, 2011). The calculation results show the value of the Bartlett's Test of Sphericity is 3453.452 (see table 3) with a significance level of 0.000 which means there is a significant correlation between observed variables. The calculation results of KMO of 0.921 indicates that the adequacy of the sample is very good. 


\section{Table 3}

KMO and Bartlett's Score

\begin{tabular}{lll}
\hline \multicolumn{2}{c}{ KMO and Bartlett's Score } \\
\hline Kaiser-Meyer-Olkin Measure of Sampling Adequacy & 0.921 \\
Bartlett's Test of Sphericity & Approx. Chi-Square & 3453.452 \\
& df & 0.496 \\
& Sig. & 0.000 \\
\hline
\end{tabular}

Note. $\mathrm{df}$ (degree of freedom) with significant about 0.000 .

Factors Rotation - The next step in factor analysis is to factor rotation to maximize the grouping of variables. The rotation used in this study is the Varimax method as it seeks to maximize the amount of variance in the factor load (Chizanah \& Hadjam, 2011). A variable may have a high or low average load factor or loading factor in each variable. Rotation results that have been adapted to the concept of loading factors and similarities with the grid on the scale (see table 4).

\section{Table 4}

Results of factors rotation

\begin{tabular}{|c|c|c|c|c|c|}
\hline Number of item & Honesty & Fairness & Respect & Trust & Responsibility \\
\hline 1 & 0.642 & & & & \\
\hline 9 & 0.633 & & & & \\
\hline 17 & 0.611 & & & & \\
\hline 24 & 0.510 & & & & \\
\hline 31 & 0.486 & & & & \\
\hline 2 & & 0.604 & & & \\
\hline 10 & & 0.514 & & & \\
\hline 25 & & 0.675 & & & \\
\hline 30 & & 0.429 & & & \\
\hline 4 & & & 0.614 & & \\
\hline 20 & & & 0.781 & & \\
\hline 26 & & & 0.649 & & \\
\hline 5 & & & & 0.485 & \\
\hline 6 & & & & 0.525 & \\
\hline 27 & & & & 0.378 & \\
\hline 15 & & & & & 0.691 \\
\hline 16 & & & & & 0.565 \\
\hline
\end{tabular}

The above rotation data shows that the results of the overall factor analysis resulted in a final item of 17 items, with honesty (5 items), fairness (4 items), respect (3 items), trust (3 items), and responsibility (2 items).

\subsection{Testing of Concurrent Validity}

This validity test is performed on a sample $(n=194)$ with equitable demographic deployment in each aspect. The assumption test of data normality is done to find out whether the data of the measurement result are normally distributed or form a normal curve (see table 5). The analysis used to test this is the One-Sample Kolmogorov-Sminov Test. The data is said to be normally distributed if it has a probability value greater than $0.05(p>0.05)$.

\section{Table 5}

Testing of Normality

\begin{tabular}{lrrrrrl}
\hline \multicolumn{1}{c}{ Scale } & Mean & Max & Min & SD & Kolmogorov-Sminov Z & Interpretation \\
\hline Academic Integrity & 72.6598 & 85.00 & 22.00 & 7.42686 & 0.965 & Normal \\
Optimism & 39.1082 & 50.00 & 10.00 & 5.66176 & 1.404 & Normal \\
\hline
\end{tabular}

Note. Both of scale are normal. 
The reliability estimation approach used in this study is the internal consistency reliability of alphaCronbach. The reliability coefficient ranges from the score of 0.00 to 1.00 with the assumption that close to 1.00 the more reliable the measuring instrument. The reliability of the academic integrity scale is 0.866 and the optimism is 0.765 (see table 6). For optimism scale, the researcher eliminates unfavorable item as the main requirement in this research.

\section{Table 6}

Results of Reliability Coefficients of Scale

\begin{tabular}{lccc}
\hline \multicolumn{1}{c}{ Scale } & Cronbach's Alpha & Alpha on Standardized Item & Total of Item \\
\hline Academic Integrity & 0.866 & 0.876 & 17 \\
Optimism & 0.765 & 0.776 & 10 \\
\hline
\end{tabular}

Note. Each of scale has a good reliability scores that shows good measurement. The scores of the alpha on standardized item is modified and adapted by the original scores.

In the above correlation calculation results, academic integrity is significantly correlated (0.01) with optimism (see table 7), with the correlation coefficient of 0.694 . This result shows that there is a strong relationship between academic integrity and optimism.

Table 7

Correlation between Academic Integrity and Optimism

\begin{tabular}{|c|c|c|c|}
\hline Scale & Pearson Correlation & Academic Integrity & Optimism \\
\hline Academic Integrity & $\begin{array}{l}\text { Sig. (2-tailed) } \\
\text { N (194) }\end{array}$ & 1 & 0.694 \\
\hline Optimism & $\begin{array}{l}\text { Sig. (2-tailed) } \\
\text { N (194) }\end{array}$ & 0.694 & 1 \\
\hline
\end{tabular}

Note. Correlation is significant at the 0.01 level (2-tailed).

In the final process is the presentation of the academic integrity scale consisting of 17 items that have good psychometric properties and are able to measure based on the concepts and the corresponding context (see table 8).

Table 8

Academic Integrity Scale (AIS)

\begin{tabular}{|c|c|c|}
\hline Dimension & $\begin{array}{l}\text { Number } \\
\text { Item }\end{array}$ & Statement \\
\hline \multirow[t]{5}{*}{ Honesty } & 1 & For me to be honest it starts from myself. \\
\hline & 2 & Honesty trains us to believe in our abilities. \\
\hline & 3 & I really appreciate friends who do the tasks with their own ability. \\
\hline & 4 & I am sure that any work done honestly results will be satisfactory. \\
\hline & 5 & Originality of ideas is an important thing to have when writing. \\
\hline \multirow[t]{4}{*}{ Fairness } & 6 & I am happy to pass the course material to my friend. \\
\hline & 7 & I am glad when a friend asks my idea in doing the lecture work. \\
\hline & 8 & I am active to participate in academic activities inside and outside of the campus. \\
\hline & 9 & I love studying other people's research results. \\
\hline \multirow[t]{3}{*}{ Respect } & 10 & All students have equal opportunities to get involved in campus activities. \\
\hline & 11 & Regular academic evaluation is very important in the learning process. \\
\hline & 12 & Trusting each other's friends is a solid foundation for collaboration on campus. \\
\hline \multirow[t]{3}{*}{ Trust } & 13 & $\begin{array}{l}\text { I like to discuss how to cite the reference sources that lecturers present in the } \\
\text { classroom. }\end{array}$ \\
\hline & 14 & For me preparing the material before the lecture is a natural thing. \\
\hline & 15 & I enjoy discussing college assignments with friends. \\
\hline \multirow[t]{2}{*}{ Responsibility } & 16 & Getting a scholarship is like having a responsibility to serve the nation. \\
\hline & 17 & I feel a good image of campus is a shared responsibility. \\
\hline
\end{tabular}




\section{Discussion}

In general, the semi-construction process in this study yields scores relevant to each psychometrics property measured. The process of assessment and translation into indicators and items are two things requiring recurrent understanding and review to obtain the good item (Hinkin et al., 1997). A clear theoretical source will provide ease in doing scale construction. So when you want to create a good measuring tool, information obtained from the main source will be very helpful in the operationalization process an item (Beaton, Bombardier, Guillemin, \& Ferraz, 2000).

This research uses a semi-construction approach which aim is easier for a researcher in seeing and increasing number of indicator as result of the operationalization of variable. Based on the information obtained by using open-ended questionnaire, there are several weaknesses so that the information obtained reduces the maximization of data (Hinkin et al., 1997). At this stage, the researchers searched for an overview of the concepts built around 60 respondents in the study population. But in the coding process, many answers from respondents who did not have a correlation with the constructs measured or perhaps the respondent's answer is limited to only a few sentences. In the part of things that must be clear is the form of questions and the question itself is the purpose to reveal the experience of respondents who must be made interesting and clear (Finn \& Kayande, 2004).

The result of information from the open-ended questionnaire process will help in explaining and making an item in scale. The number of created items should be 4-5 times more than the final scale target. The reason is to anticipate if in the next stage the item many fallen and also facilitate in choosing items with the best factor loading (Brabcova, Krsek, Kohout, \& Zarubova, 2014). The targets of the final items on this academic integrity scale is 15 items and the number of items are 50 initials. After analyzing the contents by 25 raters, it turns out there are 7 items that died because of having value $\mathrm{v}$ under criteria that are 0.63 (Aiken, 1985). This fallen item has an incompatibility with the measured aspect also contains abstract statements and the use of inappropriate words (Crocker et al., 2008).

Different power test is done to give weight to the item so as to distinguish aspect to be measured in the item. The criteria given by (Azwar, 2016) regarding the minimum limit of 0.3 , at least yield a stronger item and the rest of the items after this stage amounted to 32 items, with 11 fallen elements. These falling items are predicted to have bad characteristics and are unable to differentiate the choice of respondents. With this discrimination below 0.3 , the suitability of the items in each aspect and the totals becomes unclear and even one item is negatively charged. A thorough revision of the quality of the statements becomes crucial in generating strongly differentiated items.

The next step is to test the validity of the construct by using confirmatory factor analysis (CFA). The CFA is used to test the extent to which the items in that factor examine the appropriate academic integrity context (Thompson, 2004). The number of samples used has exceeded the minimum limit of factor analysis $(\mathrm{n}=254)$, so it can be predicted to have a large KMO value (0.921). The results of the KMO stated that the number of samples is feasible to test for factor analysis (Gudono, 2016). Unlike the KMO score, the variance value generated from this scale is $52 \%$. This shows that the scales on the scale are only able to explain $52 \%$ of the cumulative data dissemination. One that results in the value of variance that has not been maximally being the choice of respondents who are statistically uneven and there are some items that do not fit into certain factors.

The results of factor extraction before mutation were overlapping and many overlapping elements were observed in several factors. After using the rotation still, there are some items that overlap in several factors. This assumes that there is still a fallacy from the aspect measured by the item (Gudono, 2016). Items have not been able to independently measure the factors to be measured. From the 32 items measured, there are only 17 items in the final scale that are statistically good and measure the collapse of this academic integrity. This number is indeed positively correlated with the initial target of only 15 items. But to be considered is the statement items 
on each aspect there is at least 2-3 item strongly independent and does not allow the occurrence of overlap.

In testing the validity criteria with a scale that is already reliable before, in this case, the scale of optimism. The construct of academic integrity has a significant correlation with the scale of optimism $(\mathrm{n}=194)$. Thus this scale is able to measure aspects or constructs that are measured independently and can be a predictive scale to the scale of optimism. This happens, one of which is the suitability of the two concepts that are equally measuring individual positive characters. The academic integrity scale has a high reliability-coefficient $(r=$ 0.866), with a total of 17 items. This scale illustrates the concept of academic integrity with 5 aspects with each aspect being strongly interrelated and single-dimensional. Versions of this scale illustrate the toughness of its psychometric properties because they are designed and constructed on the basis of strong criteria and are procedurally eligible to be used in future studies.

\section{Implications \& Recommendation}

This study produces a scale with a good psychometric property strength, with a demonstrated systematic process and reliable calculations. The scales of academic integrity are derived from a series of qualitative tests first which are then reinforced by quantitative analysis. The final item contained in this scale is 17 items with a strength of reliability in the range of 0.866 . This provides information that the scale created has already passed the appropriate psychometric stages despite the eventual ultimate expectation of the fallen item. This is an important concern one of which is determined in the early stages of clarity of information about the variables. Future studies are expected to be able to use more modern and varied statistical procedures for more comprehensive measurement results. In addition, the number of samples to be taken is further developed and also adds some additional variables that could be closely related to academic integrity.

Acknowledgements - Many thanks to Indonesia Endowment Fund for Education (LPDP), Ministry of Finance Republic of Indonesia who has provided support and sponsorship so that I can get a chance to enroll in the postgraduate program of psychology at UGM.

\section{References}

Aiken, L. R. (1985). Three coefficients for analyzing the reliability and validity ratings. Educational And Psychological Measurement, 45. https://doi.org/10.1177/0013164485451012

Azulay, I. R., Barnes, E. R., \& Gilleland, D. (2013). Academic integrity in the online learning environment for health sciences students. Nurse Education Today. https://doi.org/10.1016/j.nedt.2013.06.002

Azwar, S. (2016). Test construction of cognitive abilities [Konstruksi tes kemampuan kognitif]. Yogyakarta: Pustaka Belajar.

Bazzy, J. D., \& Woehr, D. J. (2017). Integrity , ego depletion , and the interactive impact on counterproductive behavior. Personality and Individual Differences, 105, 124-128. https://doi.org/10.1016/j.paid.2016.09.037

Beaton, D. E., Bombardier, C., Guillemin, F., \& Ferraz, M. B. (2000). Guidelines for the process of cross-cultural adaptation of self-eeport measures. SPINE, 25, 3186-3191. https://doi.org/10.1097/00007632-200012150-00014

Boyle, G. J., Saklofske, D., \& Matthewes, G. (2015). Measures of personality and social psychological constructs. Oxford: Elsevier : Academic Press.

Brabcova, D., Krsek, P., Kohout, J., \& Zarubova, J. (2014). Psychometric properties of the modified Czech version of the children self-report quality-of-life measure for children with epilepsy (CHEQOL-25). Epilepsy \& Behavior, 33, 31-38. https://doi.org/10.1016/j.yebeh.2014.02.013

Bultas, M. W., Schmuke, A. D., Davis, L., \& Janice, L. (2017). Crossing the line : College students and academic integrity in nursing. Nurse Education Today. https://doi.org/10.1016/j.nedt.2017.06.012

Chizanah, L., \& Hadjam, M. N. R. (2011). Construct validity of sincere : Exploratory factor analysisi of sincere 
scale [Validitas konstruk ikhlas : Analisis faktor eksploratori terhadap instrumen skala ikhlas]. Jurnal Psikologi, 38(2), 199-214.

Comas-forgas, R., \& Sureda-negre, J. (2010). Academic plagiarism : Explanatory factors from students's perspective. Journal Acad Ethics, 8, 217-232. https://doi.org/10.1007/s10805-010-9121-0

Craig, S. B., \& Custafson, S. B. (1998). Perceived leader integrity scale : An instrument for assessing employee perceptions of leader integrity. Leadership Quarterly, 9(2), 127-145. https://doi.org/10.1016/S1048-9843(98)90001-7

Crocker, L., Crocker, L., Alglna, J., Staudt, M., Mercurio, S., Hintz, K., \& Walker, R. A. (2008). Introduction to classical and modern test theory. United State of America: Cengage Learning.

Curtin University. (2015). Academic integrity, student guidelines for avoiding plagiarism. Perth, Australia.

Devine, C. A., \& Chin, E. D. (2018). Integrity in nursing students : A concept analysis. Nurse Education Today, 60(October 2017), 133-138. https://doi.org/10.1016/j.nedt.2017.10.005

Finn, A., \& Kayande, U. (2004). Scale modification : alternative approaches and their consequences. Journal of Retailing, 80, 37-52. https://doi.org/10.1016/j.jretai.2004.01.003

Firmantyo, T., \& Alsa, A. (2016). Academic integrity and academic anxiety in facing national exam on students [Integritas akademik dan kecemasan akademik dalam menghadapi ujian nasional pada siswa]. PSIKOHUMANIORA: Jurnal Penelitian Psikologi, 1(1), 1-11.

Fortmann, K., Leslie, C., \& Cunningham, M. (2002). Cross-cultural comparisons of the reid integrity scale in Latin America and South Africa. International Journal of Selection and Assessment, 10(June), 98-108.

Francis, C., Clark, A., \& Erskine, J. (2015). Academic integrity during online exams for distance learning. Journal of the Academy of Nutrition and Dietetics, 115(9), A50. https://doi.org/10.1016/j.jand.2015.06.172

Gudono. (2016). The analysis of multivariate data [Analisis data multivariat]. Yogyakarta: BFFE-Yogyakarta.

Herqunanto. (2013). Plagiarsim, the collapse of the walls of academic honesty [Plagiarisme, runtuhnya tembok kejujuran akademik]. eJKI, 1(1), 1-3.

Hinkin, T. R., Tracey, J. B., Enz, C. A., \& Tracey, J. B. (1997). Scale construction: Developing relaible and valid measurement instruments. Journal of Hospitality \& Tourism Research, 21(100). https://doi.org/10.1177/109634809702100108

Jahja, A. S. (2007). Academic integrity in building professional human resources in college: Case academic dishonesty STIE Perbanas [Integritas akademik dalam membangun sumber daya manusia profesional di perguruan tinggi: Kasus academic dishonesty STIE Perbanas]. Jurnal Ilmu Pendidikan, 14(1), 46-61.

Jimenez, D. F., \& Garza, D. N. (2017). Predatory publishing and academic integrity: A perspective statement on retraction of neurosurgical publications: A systematic review. World Neurosurgery. https://doi.org/10.1016/j.wneu.2017.05.157

Kemendikbud RI. (2003). Law of the Republic of Indonesia number 20 of 2003 on national education system [Undang-undang Republik Indonesia nomor 20 tahun 2003 tentang sistem pendidikan nasional]. Jakarta.

Keohane, N. (1999). The fundamental values of academic integrity. The Center for Academic Integrity, Duke University, (October), 1-12. Retrieved from http://www.academicintegrity.org/icai/assets/FVproject.pdf

Kisamore, J. L., \& Jawahar, I. M. (2007). Academic integrity : The relationship on misconduct contemplations. Journal of Business Ethics, 75, 381-394. https://doi.org/10.1007/s10551-006-9260-9

Lim, E., \& Nather, A. (2015). What is plagiarism. In Planning your research and how to write it (pp. 283-293). World Scientific. https://doi.org/10.1142/9789814651059_0016

Mauler, F. (2006). Integrity matters. European Pharmaceutical Contractor, 5(AUTUMN), 114-117.

Mccann, J., \& Holt, R. (2009). Ethical leadership and organizations : An analysis of leadership in the manufacturing industry based on the perceived leadership integrity scale. Journal of Business Ethics, (87), 211-220. https://doi.org/10.1007/s10551-008-9880-3

Mulyana. (2010). Prevention of plagiarism in writing thesis: Efforts to strengthen the formation of character in the academic world [Pencegahan tindak plagiarisme dalam penulisan skripsi: Upaya memperkuat pembentukan karakter di dunia akademik]. Cakrawala Pendidikan, 29, 59-71. 
Park, E., Park, S., \& Jang, I. (2013). Academic cheating among nursing students. Nurse Education Today, 33(4), 346-352. https://doi.org/10.1016/j.nedt.2012.12.015

Peterson, C., \& Seligman, M. E. P. (2004). Character strengths and virtues: A handbook and classification. Londong-England: Oxford Univerisity Press.

Scheler, M., \& Carver, C. S. (1987). Dispositional optimism and physical well-being: The influence of generalized outcome expectancies on health. Journal of Personality, 55(2), 169-210. https://doi.org/10.1111/j.1467-6494.1987.tb00434.x

Thompson, B. (2004). Exploratory and confirmatory factor analysis. Washington: American Psychological Association.

Wahyono, T. (2004). The role of optimism, self-efficacy in change and the perceived support of the organization towards employees' commitment to organizational change in production employees [Peran optimisme, efikasi diri dalam perubahan dan dukungan yang dirasakan dari organisasi terhadap komitmen karyawan tentang perubahan organisasi pada karyawan bagian produksi]. Universitas Gadjah Mada. 
Ramdani, Z. 